
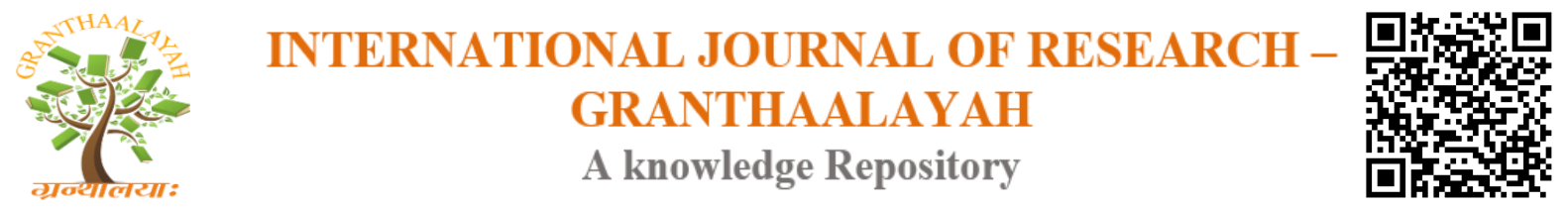

Management

\title{
ASSESSING ENTERPRISER PROFILES ON ENTREPRENEURIAL MANAGERIAL ACTIVITIES IN ELDORET, KENYA
}

\author{
Mary Nyiva Mwaniki ${ }^{1}$, Dr.Lydia Maket ${ }^{2}$ \\ ${ }^{1}$ Department of Entrepreneurial Studies, Moi University \\ ${ }^{2}$ Department of Development Studies Moi University
}

\begin{abstract}
The purpose of this research is to analysis of enterpriser profiles on entrepreneurial managerial in Bungoma, Kenya .Efforts have been made to support entrepreneurial managerial activities training and the provision of consultative services; interestingly, the failure rate still remains high Neither research on the entrepreneur personality nor enterpriser profiles have demonstrated a decisive influence on entrepreneurial managerial activities. The study adopted a post-positivism research, with research design of explanatory survey. The target population and sample size were adopted from a thesis selected from Eldoret, Towns .Data was analyzed quantitatively using techniques such as: Multivariate analysis, structural equation modeling. Finding indicates: entrepreneurial competencies, mentoring, enterpriser profile and enterprise success dimensions were sufficiently reliable and valid to be included in the subsequent model testing. The measurement model results suggest that the model provides a reasonably good fit and thus it was suitable .The CFA results supported the measurement model.
\end{abstract}

Keywords: Entrepreneurial; Managerial; Activities.

Cite This Article: Mary Nyiva Mwaniki, and Dr.Lydia Maket. (2017). "ASSESSING ENTERPRISER PROFILES ON ENTREPRENEURIAL MANAGERIAL ACTIVITIES IN ELDORET, KENYA.” International Journal of Research - Granthaalayah, 5(12), 368-376. https://doi.org/10.29121/granthaalayah.v5.i12.2017.523.

\section{Introduction}

\subsection{Background}

While there may be many categories of the entrepreneur characteristics, prior studies have highlighted need for achievement, locus of control and risk-taking propensity as the "Big Three" entrepreneurs' individual characteristics that influence venture success and performance (Chell, 2008). However, it is not clear how such characteristics influence enterprise success of women entrepreneurs. Moreover, studies on the mediating effect of enterprisers profile on the relationship between entrepreneurial competencies and enterprise success are scanty. 
It is reported that, entrepreneurs operate in a competitive and dynamic business environment and as the environment becomes more complex, owner/managers encounter many challenges which interfere with their chances of success.

Scholars Kiganane, Bwisa \& Kihoro (2012) found that entrepreneur characteristics affect the overall success of a firm and have a direct effect on business performance. To date, the study on psychological characteristics and entrepreneur success in Kenya are still less especially among women entrepreneurs, similarly, lack of research on women success also has limited the understanding on the characteristics which contribute to their success. This raises the need to undertake a research on entrepreneurial competencies and enterprise success among women entrepreneurs.

Enterprises profile refers to relatively stable, consistent, and enduring internal characteristic that are inferred from a pattern of behaviors, attitudes, feelings, and habits in the individual. Various types of entrepreneurial characteristics have been suggested and examined (Chell, 2008; Li \& Jia, 2015; McClelland, 1987; Ogundele, 2007; Ranasinghe, 2012). Among them are needs for achievement, risk taking, self-confident and creative and innovative to mention but a few. To develop more chances of entrepreneurial success, it is worthwhile to recognize and sharpen the psychological characteristics among entrepreneurs (Jain and Ali, 2012). Moreover, studies on the mediating effect of enterprisers profile on the relationship between entrepreneurial competencies and enterprise success are scanty. The performance, growth and success of Small and Medium enterprises depend on the competencies of the entrepreneur. The entrepreneur holds a critical position in operating the business (Michelmore, Rowley, \& Shiu, 2014). Therefore an understanding of competencies and especially women entrepreneur's competencies that drive business success is important. Over the years, entrepreneurial competencies have been recognized as central determinants of successful entrepreneurship (Colombo \& Grill, 2005; Michelmore \& Rowley, 2010; Song Ng \& Hung Kee, 2012). Researchers have attempted to investigate entrepreneurial competencies and how they affect business success. This research considers the following objectives: Examine the association between Managerial competence and Entrepreneurial managerial activities; analyze the relationship of Behavioral Competence and Entrepreneurial managerial activities; lastly to determine relationship of Attitudinal competence and Entrepreneurial managerial activities

\section{Literature Review}

Personality profile or traits refer to relatively stable, consistent, and enduring internal characteristic that are inferred from a pattern of behaviors, attitudes, feelings, and habits in the individual whereas competence refers to an individuals developed repertoire of skills, especially as it is applied to a task or set of tasks (VandenBos, 2007).

Researchers have extensively studied the characteristics of entrepreneurs with mixed results on its impact on small business result (Bouazza, Ardjouman \& Abada, 2015). For instance, Vecianaet, Aponte \& Urbano, (2005) noted that entrepreneur exhibit certain characteristics which contribute to their predisposition towards business success. To develop more chances of enterprise success, Jain and Ali, (2012) suggested that all entrepreneurs including women must 
recognize and sharpen their psychological/ personality characteristics. This is because enterprisers profile is part and parcel of an enterprise activity.

In a study on entrepreneur characteristics by Jane et al., (2011) examined the interaction between age and education of women entrepreneurs with business dynamics of SMEs in Kenya and the results indicated that there was a significant interaction between age and education in that the affected businesses profitability. The research sample comprised of 128 women entrepreneurs in SMEs.

Since McClelland (1961), much of the discussion in entrepreneurship has been concentrated on the individual who has been found to plays a very important role in entrepreneurship. When an entrepreneur begins a business, they bring a set of human capital to the business. Therefore, the business becomes an enlargement of the entrepreneur as an individual (Zhang \& Bruning 2011).

Similarly, in studying entrepreneurship the individual's entrepreneurial characteristics are important. Entrepreneurs' characteristics are defined as personal traits of the entrepreneur needed for venture success. Synonymous to entrepreneur characteristics is personal and psychological factors that affect business performance (Lawal, 2005; Ogundele, 2007). The profile or characteristics of an entrepreneur is regarded as one of the key factors in the enterprise success (Jasra et al., 2011).

Literature on entrepreneurs profile as a success factor has been classified into three broad categories: the entrepreneur personality, the entrepreneur biographical background and the type of the firm created (Terres, Padella-Melendez and Aguila-Obira, 2006)Tthese factors have been regarded as key factors in understanding business failure or success. The psychological approach, however hold the assumption that the entrepreneur has a different profile form the rest of the population and hence successful entrepreneurs have a different profile from others (Terres et.al., 2006).

\section{Methodology}

The study design was explanatory survey. The target population was 1000 women entrepreneurs in selected from Eldoret region. The sample size constitutes 120 respondents. Simple random and purposive sampling technique was employed. Validity, reliability and pilot study of the instrument was done.

\section{Analysis}

Data was analyzed quantitatively using techniques of multivariate analysis, structural equation modeling by AMOS ver 21. SEM is a second-generation technique known as covariance-based SEM. It offers an extensive, scalable, also a type of model nested comparison and flexible causal-modeling capabilities. A nested model is a model that uses the same variables as another model but specifies at least one additional parameter to be estimated. The model with fewer restrictions and more free parameters .which could be called a reduced model, is nested within the more restricted model, which could be called the full model. Some examples include comparing a one-factor to a two-factor model with the same variables, comparing a model which 
imposes equality constraints (two parameters are set to be equal) to a model that does not, or comparing a model that sets one or more parameters to particular values compared a model that allows them to be freely estimated.

\section{Results}

\subsection{Validation by Factor Loading and Cronbach Alpha}

Results indicate show that: The latent factors had acceptable reliability values with Cronbach's alpha $(\alpha)$ values of each individual item ranging between .745 and .923 and factor loading ranging from0.675 and 0.907 indicating that the scale was reliable. The results further indicate that managerial competencies are important when it comes to determining enterprise success of women entrepreneurs since it explained almost 30\% (29.07) of the total variance in the data set. The six extracted factors were subjected to Structural Equation Modeling (SEM). Loading for the first factor were found to be inclined towards entrepreneurial managerial activities and was named "managerial competence".

Table 1.1: Factor Loading and Cronbach Alpha

\begin{tabular}{|c|c|c|c|c|}
\hline Factors & Code & Measurement variables & Factor loading & $\begin{array}{c}\text { Cronbachs } \\
\text { Alpha }(\alpha)\end{array}$ \\
\hline \multirow[t]{7}{*}{ Managerial Competence } & $\mathrm{mc} 2$ & Information seeking & .850 & .892 \\
\hline & mc6 & Teamwork & .818 & .892 \\
\hline & $\mathrm{mc5}$ & Organizing & .802 & .896 \\
\hline & mc4 & Communication & .781 & .899 \\
\hline & $\mathrm{mc} 3$ & Systematic Planning & .779 & .903 \\
\hline & $\mathrm{mc1}$ & Decisiveness & .717 & .910 \\
\hline & mc7 & commercial thinking & .692 & 911 \\
\hline \multirow[t]{6}{*}{ 2.Attitudinal competence } & a7 & Networking & .843 & .921 \\
\hline & a5 & Ability to deal with failure & .822 & .923 \\
\hline & $\mathrm{a} 2$ & Tolerance for ambiguity & .816 & .922 \\
\hline & a6 & Service orientation & .813 & .923 \\
\hline & a4 & Concern for quality & .807 & .922 \\
\hline & a3 & Self-confidence & .747 & .931 \\
\hline \multirow[t]{5}{*}{ 5.Behavioral Competence } & b5 & Drive \& Energy & .860 & .875 \\
\hline & b6 & Flexibility & .811 & .882 \\
\hline & b7 & Result-oriented & .784 & .890 \\
\hline & b1 & Persistence & .769 & .891 \\
\hline & b3 & Innovativeness & .769 & .882 \\
\hline
\end{tabular}

After the extraction of the six components, loading for the first factor were found to be inclined towards entrepreneurial managerial activities and was named "managerial competence". The second factor explained entrepreneurial attitudes and therefore were named "attitudinal competence". The third factor focused on entrepreneurial mentor support activities and thus was named "mentoring". The fourth factor was inclined toward the attributes and traits of an entrepreneur and as a result it was named "Enterpriser Profile". The fifth factor was indicative of outcomes of entrepreneurial behaviors and as such was named "Behavioral competence". The 
last to be extracted was found to be inclined towards entrepreneurial outcomes and was named "enterprise success".

SEM was employed in this study for two main tasks: (1) confirmatory factor analysis (CFA) to corroborate the constructs established through exploratory factor analysis (i.e. testing the measurement model); and (2) testing the structural model by testing the hypotheses using path significance analysis for every construct of the research model. In addition, SEM allows for the testing of multiple structural relationships simultaneously while maintaining statistical efficiency (Hair et al., 2010).

\section{Model Fit}

It also offers a mechanism for analyzing goodness of fit of data in addition to providing modification indices that point out sources of model misfit. Also, it examines the extent to which the obtained factor structure adequately presents the covariance among items thus allowing for removal of subscales that do not represent a latent construct of interest (Muthen \& Muthen, 2006).

\subsection{Model Fit Test with Managerial Competencies Model}

In this paper, the primary interest in Structural Equation Modeling is the extent to which a hypothesized data "fits", or in other words, adequately describes the sample data. Ideally evaluation of a model fit was driven from a split of seven factors and is based on several criteria that assess Managerial Competencies model fit from a diversity of perspectives. The model fitting process involved determining the goodness-of fit between the hypothesized Managerial Competencies.

Results indicate Chisquare $=45.014, \mathrm{df}=15, \mathrm{p}=.002$ less than 0.05 significant, Model Fit test indicate good test GFI $=.92$, TLI $=.90$, results indicate good fit Hui,(2011), results are also supported by Hair et al., (2006), results harvested by RMR =.017 and RMSEA =.021 agree with the rule of thumb,Ananda (2012) says it a good model ;Nevertheless, Arbuckle (2005) suggests that model evaluation is one of the most difficult and unsettled issues related to structural equation modeling. This research considered chi-square goodness of fit (GOF) however the author assures that it was not used as a sole indictor of model fit (Hair et al., 2006)

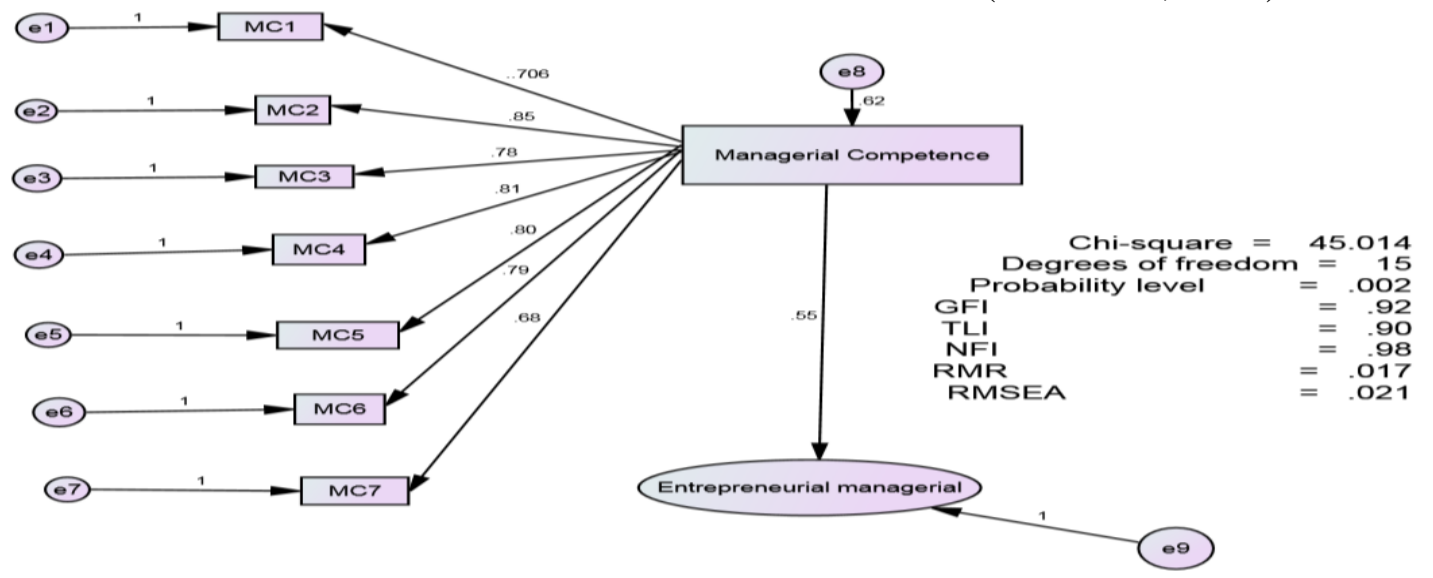

Figure1.1: Managerial Competencies model 


\subsection{Model Fit Test with Attitudinal Competencies Model}

Results indication Attitudinal competencies (figure 4.2) indicate that Chi-square $=35.014$, df $=23, \mathrm{p}=.005$, less than 0.05 significant, Model Fit test indicate GFI $=.81$ indicating poor fit, TLI $=.98$ indicating good fit, Lewis (1998), $\mathrm{RMR}=.022$ and RMSEA $=.048$ which indicated a weak results according to the rule of thumb. All the same chi-square values and $\mathrm{p}=.005$ indicated a significant influence.

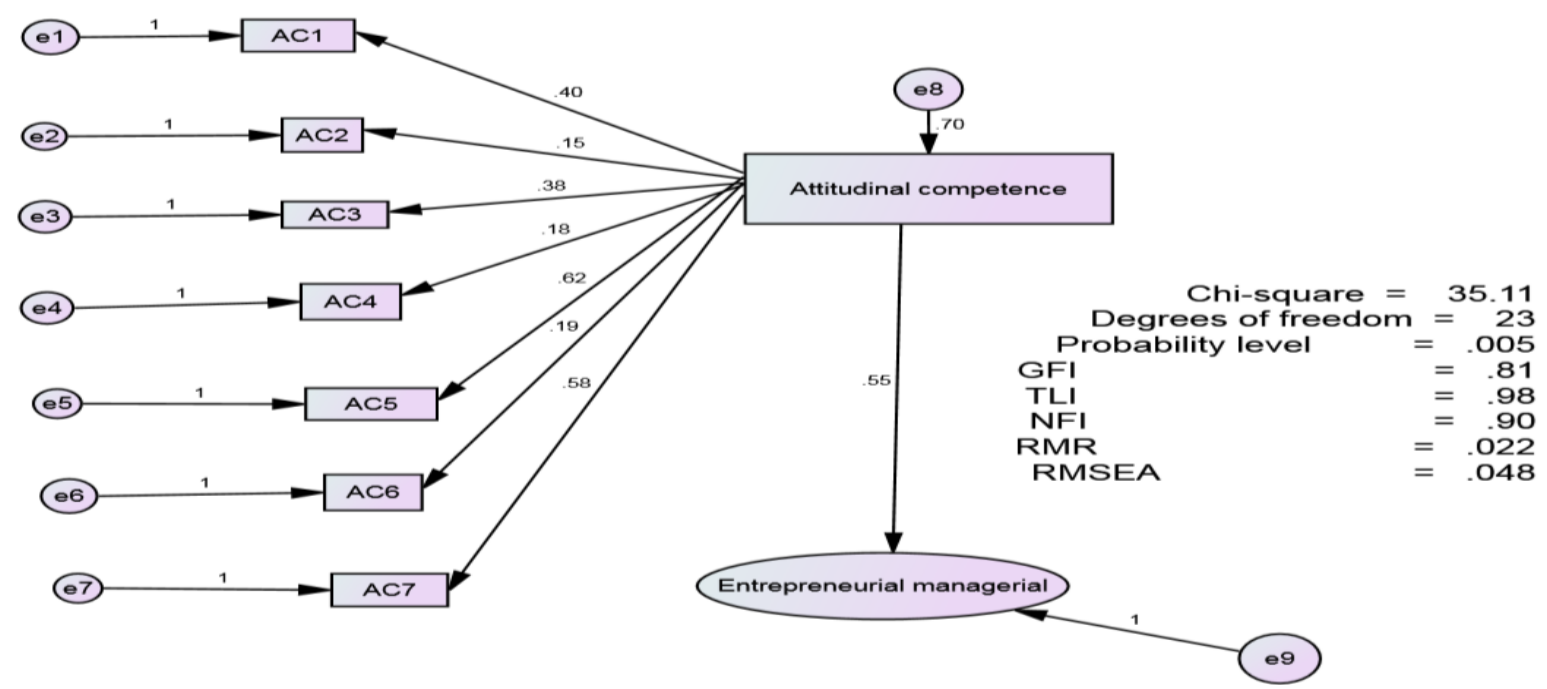

Figure1.2: Attitudinal competencies Vs Entrepreneurial managerial Model

\section{Managerial Competencies}

Managerial competencies are underlying characteristics of a person which results in superior performance of a task and include a combination of knowledge, skills, attitudes and personal oriented abilities of owner/manager to direct work streams and define outcomes (Yahiya \& Khaled, 2012). It involves problem solving, information seeking, systematic planning, communication skills, social skills, team building, organizational and other related functional competencies (Hellriegel, Jackson \& Slocum, 2008). The statement that "expresses business ideas in a clear manner" which related to managerial competency of communication had the highest mean score 3.07 and a SD of .647 while the statement "Plan and prioritizes business operations "recorded the lowest mean score. Majority, $n=117$ (39.5\%) disagreed that they planned and prioritized business operations.

Overall, managerial competence had a mean score of 2.9, standard deviation of .647 and a variance of .419. The small value of variance shows that the response points were clustered around the mean. However, the mean is lower than the average (3) on a five-point scale and indicated that most of the respondents disagreed that managerial competencies among women entrepreneurs was important in ensuring enterprise success. The minimum value of 1 indicates that a number of respondents strongly disagreed that managerial competence influenced enterprise success of women entrepreneur in Eldoret region while a maximum value of 5 indicated that there are those who strongly agreed that managerial competencies influenced enterprise success of women entrepreneurs. 


\subsection{Behavioral Competencies}

A set of eight statements for measuring behavioral competencies were presented to the respondents who were required to indicate their level of agreement or disagreement based on a five point Likert scale ranging from 1 (strongly disagree) to 5 (strongly agree). According to the results the statement 'I always seek new way to improve my business performance' had the highest mean score (4.12) while "I assume an aggressive posture to combat trends that may threaten the survival and competitive position of my business' had the lowest mean score (3.94).

The overall mean score of behavioral competence was 4.03; standard deviation was .534 and variance 0.285 . The small value of variance (.285) shows that the response points were clustered around the mean. On the other hand, the mean (4.03) was higher than the average (3) on a fivepoint scale indicating that most of the respondents were in agreement that behavioral competence influenced enterprise success of women entrepreneurs.

The minimum value of 2 indicates that there are a number of respondents who disagreed with the statement while a maximum value of 5 points to the fact that a number of respondents strongly agreed with the fact that behavioral competencies contribute to enterprise success. This shows that women entrepreneurs in Eldoret region agreed that behavioral competencies required to operate their enterprises could also lead to success in their entrepreneurial endeavors.

\section{Confirmatory Factor Analysis}

Confirmatory factor analysis (CFA) is a much more sophisticated method usually used in the advanced stages of the research process to test a theory about latent processes (Tabachnick \&Fidell, 2007). It is usually performed to estimate the factor loadings for the items measuring each construct. It is also suitable in validating and confirming the dimensionality of a set of variables (Kline, 2005), and also in investigating the extent to which established dimensionality of a particular construct fits a new sample (Muthen \& Muthen, 2006). In performing CFA, the general rule of thumb is that a minimum of three items or measured variables per latent factor is needed to provide minimum coverage of the constructs theoretical domain (Hair et al., 2010). This threshold was meeting as all the six constructs in the measurement model had a minimum of four items or variables. In CFA, correlation relationships are important, therefore all constructs are considered exogenous.

The evaluation criterial for measurement model is usually based on model fit indices namely: Chi-square $\left(\chi^{2}\right)$ test, Chi-square $\left(\chi^{2}\right) / \mathrm{df}$ ratio, Goodness-of-Fit Index (GFI), Comparative Fit Index (CFI) and Root Mean Square Error of Approximation (RMSEA), Normed Fit Index (NFI), Relative Fit Index (RFI), Tucker Lewis Index (TLI) and Root Mean Square Residual (RMR) (Hair et al., 2010). These indices were used to assess the model fit for the initial, second-order and final models of the study.

The $\chi^{2}$ measure is the most generally reported measure of model fit. However, it should be noted that the $\chi^{2}$ statistics should not be considered in isolation because it is sensitive to both sample size and the degrees of freedom in the model and hence can lead to rejection of too many 
models. Byrne (2001) supports consideration of other goodness of fit indices when determining the model fit.

RMSEA has been recognized as yet one of the most informative indices of model fit (Byrne, 2001) because it takes into account the error of approximation in the population, has less stringent requirements on $\chi^{2}$, it is also less sensitive to the number of sample and parameters in the model.

\begin{tabular}{|l|l|}
\hline Fit Indices & Value \\
\hline P value of the model's Chi-Square $(\chi 2)$ & $\chi^{2}=529.741, \mathrm{df}=339, \mathrm{p}<0.05$ \\
\hline Chi-square/df & 1.563 \\
\hline Comparative Fit Index (CFI) & .964 \\
\hline Normed Fit Index (NFI) & .906 \\
\hline Goodness of Fit Index (GFI) & .888 \\
\hline RMR (Root Mean Square Residual) & .036 \\
\hline Root Mean Square Error of Approximation (RMSEA) & .044 \\
\hline PCLOSE & .930 \\
\hline
\end{tabular}

Source: Researcher, (2017)

\section{Conclusion}

Based on reliability and validity indicators, it was concluded that entrepreneurial competencies, mentoring, enterpriser profile and enterprise success dimensions were sufficiently reliable and valid to be included in the subsequent model testing. Hence, the measurement model (CFA) results suggested that the model was reasonably a good fit and thus it was suitable in structural model. The CFA results supported the measurement model, rule of thumb was adhered to in the three items.The threshold was meet as all the six constructs in the measurement model had a minimum of four items or variables. RMR and RMSEA are agreed with the rule of thumb. Overall, managerial competence had a mean score of 2.9, standard deviation of .647 and a variance of .419.The small value of variance shows that the response points were clustered around the mean ,the mean was lower than the average, however finding on Attitudinal competencies Model Fit test indicate GFI $=.81$ indicating poor fit

\section{References}

[1] Adeyemi, S. (2007). Nigerian women Entrepreneurship and Their Personality Traits. Journal of Intellectual, Scientific and Cultural Interests, 7, 179-188.

[2] Ahmad, N., Halim, H. A \& Zainal, M. S. (2010). Is Entrepreneurial Competency The Silver Bullet for SME Success in a Developing Nation? Interdiscilinary Journal of Contemporary Research in BUsiness, 2(1), 217- 236.

[3] AnandaKumar Palaniappan (2010). University of Malaya, Faculty of Education, Tel: 0199310956; 03-79675046. Prof.Dr.Ananda Kumar Palaniappan (PhD) education Email: ananda4989@yahoo.com; anandak@um.edu.my

[4] AnandaKumar Palaniappan (2010). University of Malaya, Faculty of Education, Tel: 0199310956; 03-79675046. Prof.Dr.Ananda Kumar Palaniappan (PhD) education Email: ananda4989@yahoo.com; anandak@um.edu.my

[5] Appleton, E., (1999). "How to Survive ERP”, Datamation, March. 
[6] Arbuckle, J., (2006).User's Guide. USA: Amos Development CorporationChell, E. (2008). The Entrepreneur Personality: A social Costruction. East Sussex: Routledge.

[7] Cherchill, N. C \& Lewis, V.L. (1983). Stages of Small Business Growth. Harvard Business Review, 61(3), 30-50.

[8] Choe, K \& Loo, S. (2013). Exploratory Study on The relationship Between Entrepreneurial Attitude and Firm Performance. Journal of Asian Social Science, 9(4), 144.

[9] Choi, D. Y \& Gray, E. R. (2008). Socially Responsible Entrepreneurs: What do they do to create and build their companies. Journal of Business Horizon, 51, 341-352.

[10] Choo, C. W. (2006). The Knowing Organization: how organizations use information to Construct Meaning, Create Knowledge, and Make Decisions. New york: Oxford University Press.

[11] Colbert, B. (2004). The complex Resource based View: Implication for Theory and Practice in Strategic Human Resource Management. Journal of the Academy of Managemnt, 29(3), 341-358.

[12] Colombo, M. G \& Grilli, L. (2005). Founders Human Capital and Growth of New TechnologyBased Firms: A Competence-Based View. Research Policy, 34(6), 795-816.

[13] McClelland, D. (1987). Characteristics of Successful Entrepreneurs. Journal of Creative Behaviour, 21(1), 18-12.

[14] McClelland, D. C. (1961). The Achieving Society. New Jersey: Princeton.

[15] McClelland, D., Atkinson, J. W., Clark, R \& Lowell, E. (1953). The Achievement Motive. New York: Appleton.

[16] McKevitt, D \& MArshall, D. (2015). The Legitimacy of Entrepreneurial Mentoring. International Journal of Entrepreneurship behaviour and Research, 21, 263-280.

[17] Mintzberg, H. (1973). The Nature of Managerial Work. New York: Harper \& Row.

[18] MItchelmore, S \& Rowley, J. (2010). Entrepreneurial Competencies: A literature Review and Development Agenda. Internationl Journal of Entrepreneurship Behabviour and Research, 16(2), 92-111.

[19] Morris, S., A., Marshall, T., E., \& Rainer, R., K., (2012). Impact of User Satisfaction and Trust on Virtual Team Members. Information Resources Management Journal, 15 (2): 23 - 69.

[20] Orlikowski, W., J., (2013). Using Technology and Constituting Structures: A Practice Lens for Study using Technology in Organizations. Organization Science, 11(4), 404-428.

[21] Sanja, Michael, Mutongwa , (2017).PhD Thesis, Department of Computer Science and software engineering, School of Informatics and Innovation Systems,,Jaramogi Oginga Odinga University of Science and Technology Page;120-140;168 -170

[22] Saxenian, A., (1994). Regional advantage: Culture and competition in Silicon Valley and Route 128. Cambridge: Harvard University Press.

[23] Serida, J., Morales, O., \& Nakamatsu, K. (2012). Global Entrepreneurship Monitor Peru 2011 (pp. 146). Lima: Universidad ESAN.Sessional paper no. 2 of 2005 on development of micro and small enterprises for Wealth employment creation for poverty reduction, Government printers, Nairobi 